University of Nebraska - Lincoln

DigitalCommons@University of Nebraska - Lincoln

Agronomy \& Horticulture - Faculty Publications

Agronomy and Horticulture Department

1998

\title{
Baking quality of hard winter wheat: Response of cultivars to environment in the Great Plains
}

\author{
C. J. Peterson
}

USDA-ARS

R. A. Graybosch

USDA-ARS, bob.graybosch@ars.usda.gov

D. R. Shelton

University of Nebraska-Lincoln

P. Stephen Baenziger

University of Nebraska-Lincoln, pbaenziger1@unl.edu

Follow this and additional works at: https://digitalcommons.unl.edu/agronomyfacpub

Part of the Plant Sciences Commons

Peterson, C. J.; Graybosch, R. A.; Shelton, D. R.; and Baenziger, P. Stephen, "Baking quality of hard winter wheat: Response of cultivars to environment in the Great Plains" (1998). Agronomy \& Horticulture -Faculty Publications. 140.

https://digitalcommons.unl.edu/agronomyfacpub/140

This Article is brought to you for free and open access by the Agronomy and Horticulture Department at DigitalCommons@University of Nebraska - Lincoln. It has been accepted for inclusion in Agronomy \& Horticulture -Faculty Publications by an authorized administrator of DigitalCommons@University of Nebraska - Lincoln. 


\title{
B aking quality of hard winter wheat: $R$ esponse of cultivars to environment in the $\mathbf{G}$ reat Plains
}

\author{
C.J . Peterson ${ }^{1}$, R .A . G raybosch'1, D.R . Shelton ${ }^{2} \&$ P.S. B aenziger ${ }^{2}$ \\ ${ }^{1}$ USDA -A RS, D epartment of A gronomy, U niversity of N ebraska, L incoln, NE , 68583, U.S.A.; ${ }^{2} D$ epartment of \\ A gronomy, U niversity of N ebraska, L incoln, NE , 68583, U.S.A.
}

\section{Summary}

Inconsistency of wheat end-use quality has long been a problem for the milling and baking industries, which require high levels of uniformity for modern, high speed, processing. Extensive research was conducted to characterise genetic, environmental, and biochemical factors that contribute to variation in wheat quality. Samples from 17 locations of trials with 30 cultivars grown over two years were evaluated for grain quality, milling yield, mixograph parameters and baking properties. Protein quality and composition of flour samples were determined by SDS sedimentation and size-exclusion chromatography. Test sites were monitored for soil fertility, and meteorological data was collected hourly during grain fill. A dditional grain samples and data were collected from six cultivars grown at 11 locations in 1993. Significant variation in end-use quality was observed among samples; variation was attributed to environmental effects, genotype, and their interactions. For many mixograph and baking parameters, variation attributed to environmental effects was of greater magnitude than for genotype. Increasing levels of low molecular weight ( L M W ) saline soluble proteins were related to a general decline in dough mixing properties and loaf characteristics. H owever, correlations of protein components with baking parameters were generally low, suggesting limited predictive value. $\mathrm{H}$ ours of high temperature stress $\left(>32^{\circ} \mathrm{C}\right)$ during grain fill were associated with loaf volume and SD S sedimentation volume, although in a curvilinear fashion. Increasing temperature stress initially had a positive influence on loaf volume and protein quality; however, when temperature stress exceeded 90 hours, there was a strong negative influence on baking quality. Variation among cultivars for environmental stability was indicated and cultivar responses to temperature stress varied. R elationships with meteorological data suggest opportunities to predict wheat end-use quality through environmental modelling.

\section{Introduction}

End-use quality attributes of hard winter wheat produced in the U.S. G reat Plains are inherently inconsistent, both within and over crop years. The region has a wide range of wheat production practices, dramatic fluctuations in climatic conditions, erratic disease and insect pressures, and substantial genetic diversity for quality among cultivars deployed throughout the region. These inconsistencies creates problems for the domestic milling and baking industry, which requires a high level of uni- formity in flour performance to meet the demands of automated, high-speed, processing facilities. Wheat breeders can improve overall end-use quality of cultivars through evaluation and selection. H owever, genetic improvement in processing quality may not translate into improved 'consistency' in the marketplace due to inherent variation caused by production environments.

Several researchers have shown evidence for variation in genetic response to environment for various measures of end-use quality (Peterson et al., 1992; Baenziger et al., 1985; Bassett et al., 1989; 
B usch et al., 1969). Few studies, however, have evaluated the relative influences of genotype and environment on variation in bread quality or other baked products, which are the ultimate measures of end-use quality. A more thorough understanding of the role of environment, environmental components, genotype, and genotype by environment interactions ( $G \times E)$ on end-use quality is needed. $B$ reeders must consider whether selection for quality 'stability' over environments is an important or reasonable goal, and how this might relate to current evaluation strategies for improvement in 'mean' quality. If improved stability can provide a significant economic benefit to the industry, new strategies and cost-effective methods to measure genotypic stability need to be developed.

Information and mechanisms for characterising intra-regional crop quality are currently inadequate for the domestic U S milling industry. Varietal surveys provide some indication of potential end-use quality, but most companies rely on extensive baking and quality evaluation of in-house crop surveys. Key genetic and environmental components that affect quality need to be identified and monitored to improve grain sourcing and blending to meet end-use quality specifications. $R$ ecent research by Blumenthal et al. (1993) and Corbellini et al. (see these proceedings) has suggested that high temperature stress may result in modification of protein composition and reduce end-use quality. However, before temperature or other environmental measures may be used effectively for predicting quality, cultivar responses over a wide array of production conditions need to be evaluated.

\section{M aterials and methods}

Thirty hard red winter wheat cultivars were grown in replicated trials at 10 locations in Nebraska in 1990 and 1991. G rain samples were obtained from a total of 17 environments, each location/year combination was treated as a separate environment. Cultivars were chosen based on historical importance to the $G$ reat Plains and to represent the regional diversity in end-use quality found among released cultivars during the last 30 years. L ocations repre- sented a wide array of environmental conditions and were managed using practices common to the surrounding wheat growing areas.

Six cultivars, A bilene, A rapahoe, Cimarron, $\mathrm{K}$ arl, Scout 66, and TA M -107, were grown in additional replicated trials at 11 locations in 1993. These cultivars were also included in the 1990-1991 study, providing a total of three years and 26 locations for evaluation of environmental effects on end-use quality.

$G$ rain samples were milled in a $B$ uhler ${ }^{1} L$ aboratory mill (Buhler Inc., Minneapolis, MN). Flour protein content was determined on a dry weight basis using near-infrared spectroscopy. Protein composition was evaluated using size-exclusion chromatography as described by Graybosch et al. (1996). SD S sedimentation volume was measured using approved methods ( $A$ nonymous, 1983) on a 2 g flour sample. M ixograph analyses were conducted using a $\mathrm{N}$ ational $\mathrm{M}$ anufacturing $\mathrm{M}$ ixograph ( $\mathrm{L}$ incoln, NE). M ixograph peak time was recorded as time to peak dough development, and mixograph tolerance as $\mathrm{mm}$ width of the mixograph curve two minutes past peak. A $100 \mathrm{~g}$ pup loaf baking procedure was used to evaluate loaf properties. A straight dough process with fermentation time of three hours was used and the bake formula did not include any oxidation agents. L oaf external and internal appearance was subjectively scored on a 0-12 scale, with 12 considered as excellent.

On-site or near-site weather stationswere used to collect hourly data on air temperature and relative humidity during grain fill, from anthesis to physiologic maturity, from each growing location. Environmental stresses were calculated as the cumulative number of hours of temperature stress $>32^{\circ} \mathrm{C}$ (or $>90^{\circ} \mathrm{F}$ ), or hours of relative humidity $<40 \%$ at each test site during grain filling. The grain filling period was defined based on the average maturity of cultivars grown in the trials. Weather stations and data networks were operated and maintained by the High Plains Climate Centre, Department of

\footnotetext{
${ }^{1} M$ ention of firm names or trade products does not imply that they are endorsed or recommended by the U SDA or the U niversity of N ebraska over other firms or products not mentioned.
} 
Table 1. M eans and ranges for quality parameters measured from 30 cultivars grown at 17 locations during $1990-1991$

\begin{tabular}{|c|c|c|c|c|}
\hline & \multirow[t]{2}{*}{ M ean } & \multicolumn{3}{|l|}{ R ange } \\
\hline & & O verall & Cultivars & Locations \\
\hline Flour protein $\left(\mathrm{mg} \mathrm{g}^{-1}\right)$ & 129 & $78-227$ & $112-161$ & $97-177$ \\
\hline M ixograph peak time (min) & 3.94 & $1.30-9.25$ & $2.98-5.43$ & $3.17-7.74$ \\
\hline M ixograph tolerance (mm) & 18.9 & $5.8-39.7$ & $8.3-15.7$ & $10.2-14.0$ \\
\hline A bsorption (\%) & 61.5 & $54.5-69.0$ & $59.1-66.3$ & $57.7-63.8$ \\
\hline Pup loaf volume (cc) & 940 & $615-1135$ & $847-1034$ & $767-1040$ \\
\hline External loaf (0-12) & 6.3 & $0-12$ & $3.4-9.2$ & $0.7-10.0$ \\
\hline Internal loaf grain (0-12) & 5.5 & $0-12$ & $4.4-8.4$ & $3.4-7.7$ \\
\hline SD S sedimentation volume (cc) & 32.2 & $21.4-38.6$ & $23.4-41.2$ & $21.4-38.6$ \\
\hline
\end{tabular}

A gricultural M eteorology, U niversity of N ebraska, Lincoln, NE .

Statistical A nalysis System (SA S Institute, 1985) programs were used for analyses of variance and determination of variance components. E ach location-year was treated as a separate environment, and both genotypes and environments were considered as random effects in the analyses. Cultivar means over locations were calculated for each quality parameter and correlated to measures of environmental stress.

\section{R esults and discussion}

G rain samples obtained from 30 cultivars grown at 17 locations in 1990-91 exhibited a wide range of end-use quality attributes (Table 1). Flour protein concentrations ranged from 78 to $227 \mathrm{mg} \mathrm{g}^{-1}$ with mixing requirements ranging from 1.3 to $9.25 \mathrm{~min}$ - utes. Pup loaf scores ranged from unacceptable with volumes as low as $615 \mathrm{cc}$, to superior with volumes over $1100 \mathrm{cc}$ from $100 \mathrm{~g}$ of flour. Cultivars and growing locations both contributed to diversity in quality characteristics. Ranges among location means were similar to, or somewhat larger than, ranges established among cultivar means for each of the quality parameters.

The main effects of genotype and environment and their interaction, were statistically significant sources of variation for all quality parameters (anaIyses of variance not shown). Of greater interest was the relative magnitude of variation attributable to these effects, which were compared using variance component ratios (Table 2). Variances in quality traits attributable to environmental effects over the 17 locations were from 1.2 to 4.5 times larger than genetic variances. The exception was mixograph peak time, for which the genetic variance was approximately twice that associated with environ-

Table 2. R atios of variance components associated with environment, genotype, and their interaction for quality parameters measured from 30 cultivars grown at 17 locations during 1990-1991

\begin{tabular}{|c|c|c|c|}
\hline & E nvironment/genotype & G enotype/ $\mathrm{G} \times \mathrm{E}$ & Environment/ $\mathrm{G} \times \mathrm{E}$ \\
\hline Flour protein & 2.30 & 2.71 & 6.28 \\
\hline M ixograph peak time & 4.03 & 1.85 & 7.46 \\
\hline M ixograph tolerance & 0.56 & 1.95 & 1.10 \\
\hline A bsorption & 2.13 & 1.59 & 3.39 \\
\hline Pup loaf volume & 3.19 & 0.96 & 3.07 \\
\hline External loaf & 4.52 & 0.41 & 1.86 \\
\hline Internal loaf & 1.96 & 0.30 & 0.58 \\
\hline SD S Sedimentation volume & 1.22 & 2.33 & 2.83 \\
\hline
\end{tabular}


Table 3. Correlation of end-use quality measures averaged from 30 cultivars grown at 17 locations during $1990-1991$ with number of hours of temperature $>32{ }^{\circ} \mathrm{C}$, and relative humidity less than $40 \%$, measured at each location during grain fill

\begin{tabular}{llc}
\hline & $\begin{array}{l}\text { Hours of air } \\
\text { temperature }>32{ }^{\circ} \mathrm{C}\end{array}$ & $\begin{array}{c}\text { Hours of relative } \\
\text { humidity }<40 \%\end{array}$ \\
\hline Flour protein & 0.00 & -0.40 \\
M ixograph peak time & $0.62^{* *}$ & $0.54^{*}$ \\
M ixograph tolerance & -0.02 & $-0.56^{*}$ \\
A bsorption & $-0.55^{*}$ & $-0.59^{*}$ \\
Pup loaf volume & $-0.50^{*}$ & $-0.89^{* *}$ \\
External loaf & -0.43 & $-0.85^{* *}$ \\
Internal loaf & -0.12 & 0.25 \\
SD S sedimentation volume & $-0.63^{* *}$ & $-0.87^{* *}$ \\
\hline
\end{tabular}

$*, * *$ Significant at $\mathrm{P}=0.05$ and $\mathrm{P}=0.01$, respectively.

mental effects. The importance of $G \times E$ interactions varied among the quality traits. For traits such as flour protein, SDS sedimentation, mixograph peak time and tolerance, and absorption, the interaction variance was lower than the variance associated with genotypes. H owever, for pup loaf scores and loaf volume, the $G \times E$ interaction variance was similar or larger than the genotypic variance. A relatively larger $G \times E$ variance would indicate that substantial variation in cultivar response to environmental stresses exists and there is potential to improve stability for these quality traits through evaluation and selection. While the $G \times E$ interaction variance was likely inflated due to lack of replication in the pup loaf bakes, the magnitude of these variances suggest it would be difficult to predict loaf quality and baking performance of samples from prior knowledge of genotype alone. K nowledge of

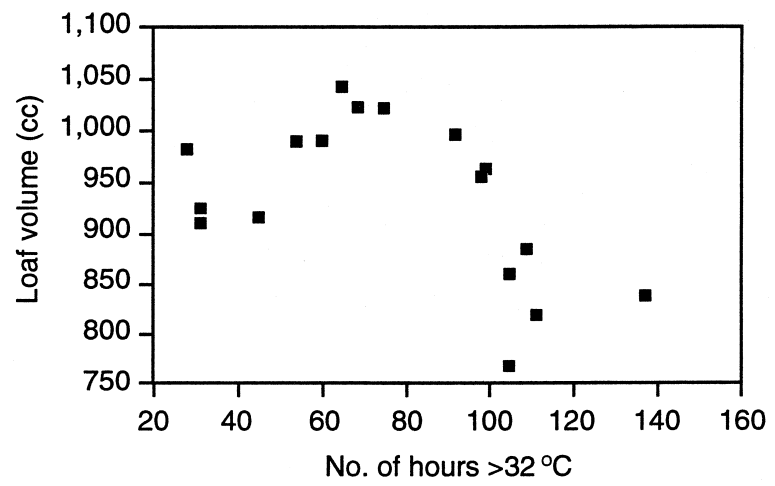

Figure 1. R elationship between location mean loaf volume and hours of temperature $>32^{\circ} \mathrm{C}$ during the grain filling period for 30 cultivars grown at 17 locations in 1990-1991 ( $y=839+4.70 x-$ $\left.0.039 x^{2} ; r^{2}=0.48\right)$. growing conditions and environmental stresses may provide relatively more predictive power for many key quality traits, including loaf volume potential and external loaf characteristics.

A ir temperature and relative humidity data from on-site or near-site weather stations were examined as potential measures of environmental stress during grain fill. Increasing temperature stress among the locations, as calculated from number of hours with air temperature $>32^{\circ} \mathrm{C}$, was correlated to a decrease in SDS-sedimentation volume, absorption and loaf volume, and an increase in mixograph peak time. However, the maximum $r$ value did not exceed $r=0.62$ (Table 3). On further examination, there was a significant curvilinear relationship of temperature stress with loaf volume and SD S-sedimentation, with $r^{2}$ values of 0.48 and 0.55 , respectively (Figs. 1 and 2). I nitially, increasing temper-

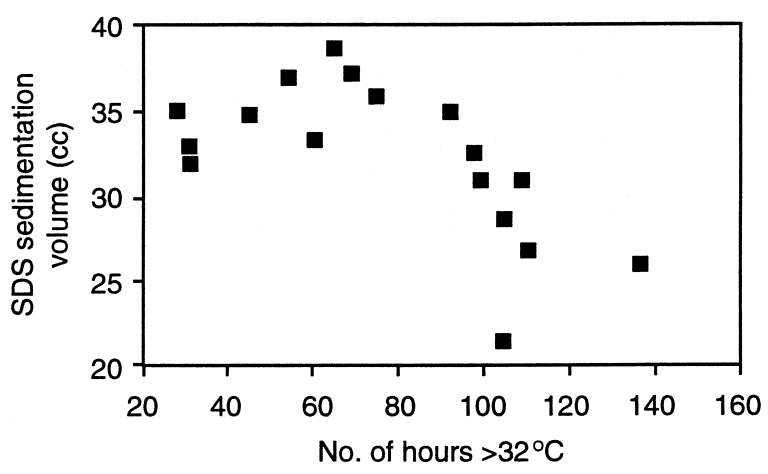

Figure 2. R elationship between location mean SD S sedimentation volume and hours of temperature $>32{ }^{\circ} \mathrm{C}$ during the grain filling period for 30 cultivars grown at 17 locations in 1990-1991 (y $\left.=29.9+0.197 x-0.002 x^{2} ; r^{2}=0.55\right)$. 


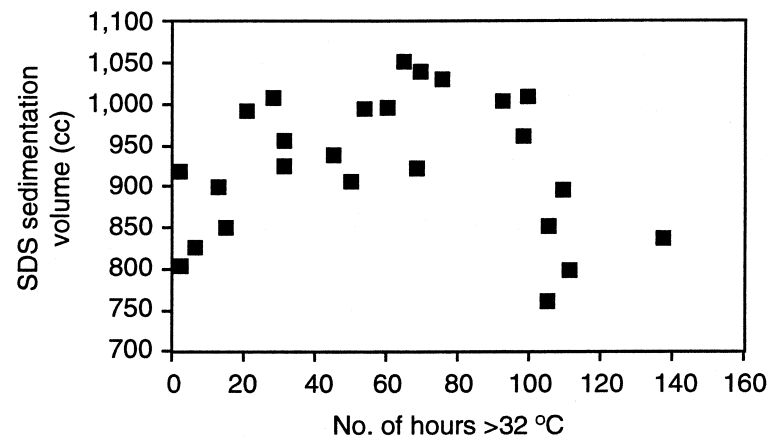

Figure 3. R elationship between location mean loaf volume and hours of temperature $>32{ }^{\circ} \mathrm{C}$ during the grain filling period for six cultivars grown at 26 locations in 1990-1991 and 1993 ( $y=844+$ $\left.4.64 x-0.04 x^{2} ; r^{2}=0.44\right)$.

ature stress resulted in increased SD S-sedimentation volume and loaf volume. $\mathrm{H}$ owever, as location temperature stress exceeded 90 hours over $32^{\circ} \mathrm{C}$, there was a sharp decline in both quality traits. In this study, total flour protein content was not related to temperature stress, rather, temperature effects were related to a change in protein quality, as measured by SD S-sedimentation volume. E nvironmental stress due to low relative humidity, calculated from number of hours of relative humidity less than $40 \%$, was related to a general decrease in enduse quality. Hours of low relative humidity had strong negative linear correlations $(r>-0.80)$ with SD S-sedimentation volume, loaf volume and external loaf scores.

G raybosch et al. (1996) examined protein compositions of these same samples via size-exclusion

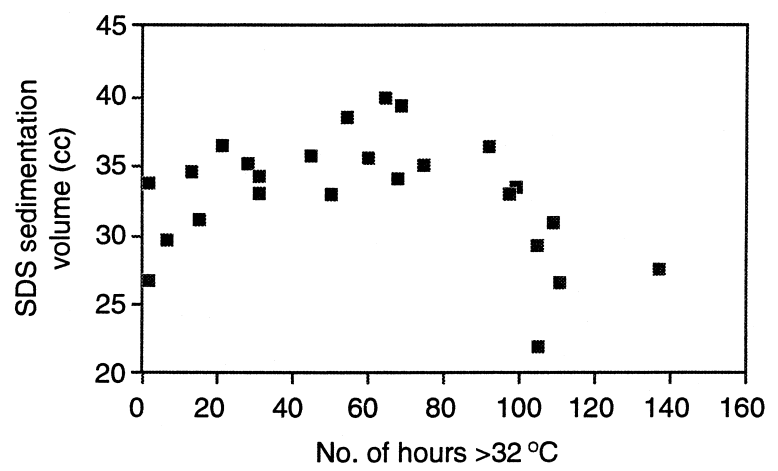

Figure 4. R elationship between location mean SD S sedimentation volume and hours of temperature $>32{ }^{\circ} \mathrm{C}$ during the grain filling period for six cultivars grown at 26 locations in 1990, 1991 and $1993\left(y=30.200+0.207 x-0.002 x^{2} ; r^{2}=0.48\right)$.

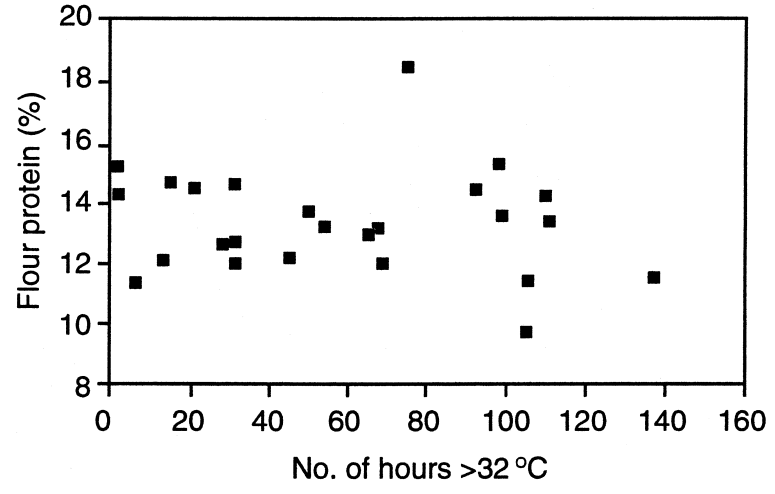

Figure 5 . R elationship between location mean protein content and hours of temperature $>32{ }^{\circ} \mathrm{C}$ during the grain filling period for six cultivars grown at 26 locations in 1990, 1991 and 1993.

chromatography and SD S-sedimentation. Proteins were fractionated into glutenins, gliadins, saline extractable proteins of $M_{r}>25 k$, and two classes of L M W proteins of $M_{r}>25 k$ based on extractability in saline. Correlations of glutenin and saline extractable proteins of $M_{r}>25 \mathrm{k}$ with loaf exterior were highly significant, at $r=0.71$ and -0.76 , respectively. I ncreasing levels of saline soluble proteins were related to a general decline in mixograph tolerance, with $r$ values ranging from -0.54 to -0.57 . H owever, there were no other correlations of size-exclusion protein components with mixing and baking quality parameters that exceeded $r=0.60$, including correlations with loaf volume. It is notable that measures of environmental stress reported here were more closely related to variation in mixing and baking quality parameters than any of the size-exclusion

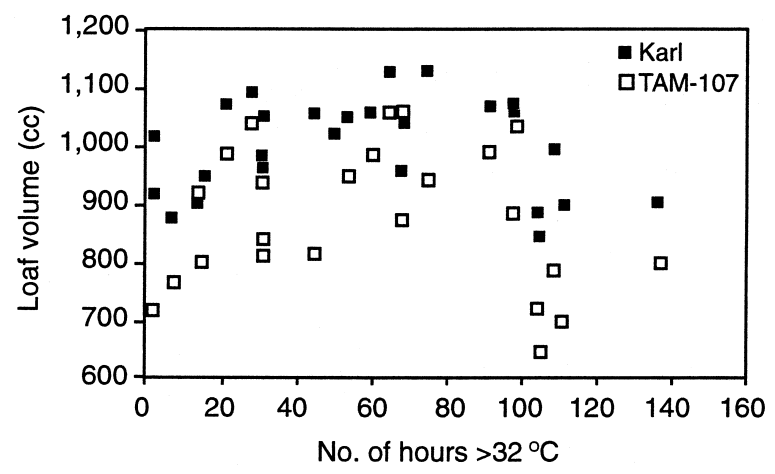

Figure 6. R elationship between loaf volume and hours of temperature $>32^{\circ} \mathrm{C}$ during the grain filling period for the cultivars TA M -107 and K arl grown at 26 locations during 1990, 1991 and 1993. 
protein components. Environmental relationships were of comparable magnitude to correlations of loaf parameters with SD S-sedimentation volume, which is a commonly used measure of overall enduse quality potential.

Influence of temperature during grain fill was further investigated using data from six varieties grown in the 1990-91 and 1993 trials. Loaf volume and SD S sedimentation volume continued to show a significant curvilinear response to temperature stress with inclusion of the 1993 data (Figs. 3 and 4) at $r^{2}=0.44$ and 0.48 , respectively. I $n$ contrast, no relationship between protein content and temperature stress was indicated (Fig. 5). G raybosch et al. (1995) confirmed that temperature stressmay result in modification of protein composition without influencing protein content. I ncreasing temperature stress was related to decreased glutenin concentration and increased levels of $L M W$ saline insoluble and HMW saline soluble proteins. Temperature stress also was related to an increase in variability of L M W saline insoluble protein levels.

A curvilinear response of loaf volume to temperature stress was found for each of the six cultivars when examined individually over the three years (data not shown). There was evidence of variation in response to temperature stress among the cultivars, as illustrated in Fig. 6. The cultivar TA M -107 showed lower average loaf volume and much greater variability in response to temperature stress as compared with $\mathrm{K}$ arl, which was relatively more stable.

\section{Conclusions}

In this study, environmental factors had a major influence on wheat end-use quality. Environmental variance in mixing and baking quality traits was often greater than the variance associated with cultivars. There were significant relationships of temperature with protein quality and loaf volume, which suggest that climatic information and weather models could be useful in predicting grain quality. G enotype by environment interactions were found to have a significant influence on quality, but contributed a smaller proportion of variability as compared with either environment or genotypic main effects. Potential existsfor some improvement in environmental stability of cultivars, especially for baking quality and loaf characteristics. A t minimum, strategies to characterise environmental response of advanced breeding lines should be developed so that 'unusual' response types, or cultivars with highly variable quality attributes, are identified. I ndustry grain sourcing could be substantially improved through integrating knowledge of cultivar distributions with key environmental measures that relate to end-use quality. A basic understanding of variation among cultivars in their response to environmental stress would further improve probability of predicting and sourcing superior quality grain for baking.

\section{R eferences}

A nonymous, 1983. A merican A ssociation of Cereal Chemists. A pproved methods of the A A C C. A A CC, St. Paul, M N.

B aenziger, P.S., R .L. Clements, M .S. M clntosh, W.T. Yamazaki, T.M. Starling, D.J. Sammons \& J.W. Johnson, 1985. E ffect of cultivar, environment and their interaction and stability analyses on milling and baking quality of soft red winter wheat. Crop Sci 22: 5-8.

B assett, L .M ., R .E . A Ilan \& G .L . R ubenthaler, 1989. G enotypex environment interactions on soft white winter wheat quality. A gron J 81: 955-960.

B lumenthal, C.S., E.W. R . B arlow \& C.W.W rigley, 1993. G rowth environment and wheat quality: The effect of heat stress on dough properties and gluten proteins. J Cer Sci 18: 3-21.

Busch, R.H., W.C. Shuey \& R. C. Frohberg, 1969. R esponse of hard red spring wheat (Triticum aestivum $L$.) to environments in relation to six quality characteristics. Crop Sci 9: 813-817.

G raybosch, R .A ., C.J . Peterson, D.R . Shelton \& P.S. B aenziger, 1995. Environmental modification of hard red winter wheat flour protein composition. J Cer Sci 22: 45-51.

G raybosch, R .A ., C.J . Peterson, D.R. Shelton \& P.S. B aenziger, 1996. Genotypic and environmental modification of wheat flour protein composition in relation to end-use quality. Crop Sci 36: 296-300.

Peterson, C.J ., R .A . G raybosch, P.S. B aenziger \& A.W. Grombacher, 1992. G enotype and environment effects on quality characteristics of hard red winter wheat. Crop Sci 32: 98-103.

SA S Institute, 1985. SA S U ser's G uide: Statistics. SA S I nstitute, Cary, NC. 